\title{
Transatlantica
}

Revue d'études américaines. American Studies Journal

Benjamin Franklin / Richard Powers

\section{“1119 Pinehurst Street”}

\section{Alison Goeller}

\section{(2) OpenEdition}

\section{Journals}

Electronic version

URL: https://journals.openedition.org/transatlantica/4585

DOI: 10.4000/transatlantica.4585

ISSN: $1765-2766$

\section{Publisher}

Association française d'Etudes Américaines (AFEA)

\section{Electronic reference}

Alison Goeller, "'11119 Pinehurst Street"', Transatlantica [Online], 2 | 2009, Online since 01 February

2010, connection on 01 February 2023. URL: http://journals.openedition.org/transatlantica/4585 ; DOI: https://doi.org/10.4000/transatlantica.4585

This text was automatically generated on 1 February 2023.

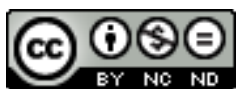

Creative Commons - Attribution-NonCommercial-NoDerivatives 4.0 International - CC BY-NC-ND 4.0 https://creativecommons.org/licenses/by-nc-nd/4.0/ 


\section{“1119 Pinehurst Street”}

\section{Alison Goeller}

1 In April 2009 I flew from Frankfurt, Germany, to Jackson, Mississippi, to attend the Centennial Celebration of Eudora Welty's birthday.

2 It was a long, overdue pilgrimage for me. I had met Welty many times, first in Oxford, Mississippi (in 1977) at a Welty symposium where I nervously stood in line to introduce myself and to tell her I was writing a dissertation on her fiction; she seemed genuinely surprised that "anyone would want to do such a thing" (her words). A few years later we met at The University of Southern Maine, at a conference on Southern literature. We were both "powdering our noses" in the ladies room! Then in 1985 a friend of mine, Emmett Gowin, invited me to his photography class at Princeton University, where Welty spoke about the connection between the short story and photography. My most serendipitous meeting, however, was when I spotted her once, in 1983, in the lobby of the Algonquin Hotel in New York, waiting for a taxi.

But unlike many of her admirers, I had never visited her in Jackson, the town where she grew up and where she spent most of her life.

4 It was marvelous to be among Welty scholars and friends who knew and loved her and who reaffirmed what I had known thirty years ago when I was a rather disingenuous grad student: that Eudora Welty was a national treasure. The centennial was a love fest, an opportunity to honor a woman who had quietly made her mark on American letters.

But for me, visiting 1119 Pinehurst, the house where she lived and worked for over seventy-five years, was the real reason I had traveled so far. I wanted to see at last the place where she worked-and where she created those intricate stories and novels that have become so important to my life and work.

6 Welty has written, famously, about place. "Place is one of the lesser angels that watch over the racing hand of fiction" (The Eye of the Story 116); "feelings are bound up in place" (118) and "place... is the named, identified, concrete, exact and exacting, and therefore credible, gathering spot of all that has been felt.... Location pertains to feeling; feeling profoundly pertains to place...." (122). 
course, Welty was writing about place in fiction, not about the writer's working space. And yet, as Francesca Premoli-Droulers has noted in Writers' Houses: “Houses play an all-important role in the lives of writers, bringing order to their memories, calming their fears, stimulating their ideas. Often it is within the walls that the artistic imagination really takes off and soars to the furthest reaches of creativity" (7). She was sixteen when her family moved to the newly built Tudor Revival house at the end of the trolley line in Belhaven just across the street from Belhaven College. Before that the Weltys had lived on North Congress Street across from where Richard Ford, a good friend of Welty's and one of America's most distinguished writers, grew up, though not when Welty lived on the street. Now a National Historical Landmark run by her nieces, 1119 Pinehurst has been restored to look as it did in the 1980's when Welty was still actively writing.

In the entranceway hangs a framed poster of the famous colored doors of Dublin, acknowledgment of Welty's love of Ireland and its writers, in particular W.B. Yeats and Elizabeth Bowen, who became a good friend and whom Welty visited many times both in London and in her home in Ireland. From the entrance one enters the living room, a comfortable and bright space, one wall of which is lined with books. I could easily imagine her receiving her guests and friends there, many of them famous -R.P. Warren, K.A. Porter, Elizabeth Bowen, Reynolds Price, for example- and serving them the good bourbon she herself loved and then escorting them to the dining room, just to the right, where stacks of books are piled on the dining room table, the metaphorical significance of which was not lost to me: here was a house where books were not only written; they were also devoured.

Indeed, Welty owned over 5000 books when she died; all of them remain in the house, shelved or else stacked in piles atop end tables and on floors in all the rooms.

We know how important books were to Eudora Welty's professional and personal life. In her autobiographical collection of essays, One Writer's Beginnings, she writes lovingly of the omnipresence of books in her home when she was growing up: the complete set of Mark Twain, the ten-volume set of Our Wonder World, containing Pilgrim's Progress, fairy tales by the Grimms brothers, Hans Christian Andersen and Aesop, and the Dickens books her mother brought from West Virginia that "had been through water and fire before I was born" (8).

But not just books. Paintings, too, some of them portraits of family members, and artifacts from her travels adorn the house at 1119 Pinehurst Street, again reminding us how important her family was to her and also how much she loved traveling: a painting simply entitled "Rome" hangs in the living room along with a portrait of Welty herself. Then there's the white feather from a swan at Coole, the mansion owned by Lady Gregory where the famous poet W.B. Yeats often retreated to write. Welty had discovered Yeats' poetry as an undergraduate student at The University of Wisconsin and later used his mythological poem "The Song of the Wandering Aengus" in her novel The Golden Apples to suggest the restlessness of her main characters.

14 I also saw her fifties' style kitchen, modest as Welty was herself, where she ruined a casserole and then wrote about it, and the sitting room, again lined with books and a framed letter from the British writer E.M. Foster. The tour guide told us this was the only air-conditioned room in the house when Welty lived there. Her nieces referred to 
it as the "cool room"; it was presumably their favorite room in the house. On hot summer days when they were visiting their Aunt Eudora, they retreated there to keep cool.

But, of course, it was Eudora's bedroom on the second floor, another large and bright room, where she usually worked, that I felt Welty's presence most intensely. Her desk and typewriter sit beneath two windows that look out over the front lawn and Belvedere College across the street. I could just imagine her sitting at the typewriter, listening to music from the college that inspired "June Recital." Her bed, a four-poster, was familiar to me from a photo I had seen of her working in her usual (but I thought unusual) fashion: cutting up pieces of her typed stories and then pinning them together in an order that pleased her. Over the fireplace are three drawings by AE (George Russell), the Irish writer and father of Diarmud Russell, Welty's long-term literary agent and friend. There are also cabinets full of the thousands of letters Welty wrote and received.

After the tour, as we were free to wander through her back garden, where she and her mother spent many pleasurable hours, I couldn't help but wonder what Welty's professional life might have been had she stayed in New York, where she was living, until her father's ill health summoned her home. Would she have had the calm, the order, the comfort that 1119 Pinehurst presumably brought to her artistic mind? At the end of One Writer's Beginnings, Welty gives us a kind of answer: "As you have seen. I am a writer who came of a sheltered life. A sheltered life can be a daring life as well. For all serious daring starts from within" (104).

\section{BIBLIOGRAPHY}

PREMOLI-DROULERS, Francesca. Writers' Houses. London: Cassell, 1995.

WELTY, Eudora. The Eye of the Story: Selected Essays and Reviews. New York: Random House, 1977. . One Writer's Beginnings. Cambridge: Harvard UP, 1984.

\section{INDEX}

Subjects: Trans'Arts

\section{AUTHOR}

\section{ALISON GOELLER}

University of Maryland University College 